\title{
Penguatan Kompetensi Guru Matematika dalam Pengembangan Media Pembelajaran Animasi Berbasis Komputer
}

\author{
Emy Siswanah \\ Universitas Islam Negeri Walisongo Semarang \\ Email : emysiswanah@walisongo.ac.id
}

\begin{abstract}
The role of learning media, especially animation media, is very important in learning mathematics especially to explain abstract problem become concrete, motivate student, stimulate student learning activity, help effectiveness of learning process. Community service activities are aimed at making teachers able to create self-directed learning media. By making their own, the teacher can increase his insight and improve his creativity in creating animation media. In this training, teachers are trained to make animation media using powerpoint and flash. Subjects assisted in this devotional activity are math teachers in Semarang City. The math teachers showed great enthusiasm in training and felt the tangible benefits of community service. Teachers can create their own animated learning media, using either powerpoint or flash.
\end{abstract}

Abstrak: Peran media pembelajaran, terutama media animasi, sangat penting dalam pembelajaran matematika terutama untuk menjelaskan permasalahan yang abstrak menjadi konkret, memotivasi siswa, merangsang kegiatan belajar siswa, membantu keefektifan proses pembelajaran. Kegiatan pengabdian kepada masyarakat ini bertujuan agar guru dapat menciptakan media pembelajaran berbasis secara mandiri. Dengan membuat sendiri, guru dapat menambah wawasannya dan meningkatkan kreativitasnya dalam membuat media animasi.Pada pelatihan ini, guru dilatih membuat media animasi menggunakan powerpoint dan flash. Subjek dampingan pada kegiatan pengabdian ini adalah guru-guru matematika di Kota Semarang. Para guru matematika menunjukkan antusiasme yang tinggi dalam mengikuti pelatihan dan merasakan manfaat yang nyata dari kegiatan pengabdian masyarakat ini. Guru dapat membuat sendiri media pembelajaran animasi, baik menggunakan powerpoint maupun flash.

Kata Kunci: media pembelajaran, animasi, guru matematika 


\section{PENDAHULUAN}

Teknologi memiliki peran yang sangat besar dalam pendidikan.Salah satu bentuk peranannya adalah adanya bentuk media pembelajaran yang semakin bervariasi, diantaranya adalah media pembelajaran berbasis animasi, yang dapat diterapkan dalam pembelajaran matematika untuk mempermudah pemahaman di kalangan para siswa. Beberapa contoh media animasi yang dapat digunakan dalam pembelajaran matematika antara lain berbasis Microsoft Powerpoint, Java, dan Macromedia Flash.

Penggunaan media pembelajaran berbasis animasi dapat memberikan kemudahan dalam pemahaman karena kesan realisme akan lebih mudah ditampilkan dengan lebih baik (Latuheru, 1998). Definisi animasi menurut Utami (2011) merupakan rangkaian gambar yang membentuk sebuah gerakan. Dengan adanya serangkaian gambar yang kemudian membentuk sebuah gerakan, maka animasi dapat menunjukkan sebuah penggambaran urutan alur suatu proses secara jelas. Dengan kelebihan ini, produk media berbasis animasi dapat digunakan sebagai media pembelajaran.

Peran media pembelajaran terutama media animasi sangat penting dalam pembelajaran matematika terutama untuk menjelaskan permasalahan yang abstrak menjadi konkret, memotivasi siswa, merangsang kegiatan belajar siswa, membantu keefektifan proses pembelajaran. Selain itu, media animasi juga dapat membuat siswa memiliki ketertarikan yang lebih tinggi dan selanjutnya membuat siswa dapat lebih memfokuskan perhatiannya karena media animasi membawa kesegaran dan sebuah variasi pengalaman belajar baru yang segartidak membosankan. Media animasi ini sangat cocok diterapkan terutama pada pelajaran yang membutuhkan visualisasi yang jelas atau proses suatu kejadian. Pada pengabdian ini, guru dilatih membuat media animasi menggunakan powerpoint dan flash.

Setelah mengikuti kegiatan pengabdian masyarakat diharapkan guru-guru matematika mampu menciptakan sendiri media pembelajaran animasi yang menarik. Diharapkan dengan adanya kegiatan ini, guru-guru matematika mempunyai pengetahuan dalam menggunakan Microsoft powerpoint dan flash untuk membantu menjelaskanmatematika.Melalui program ini diharapkan guru mempunyai pengalaman baru dalam membuat media pembelajaran yang melibatkan penggunaan teknologi terkini. Pengetahuan guru juga bertambah sehingga guru akan semakin banyak mempunyai perbendaharaan media pembelajaran. 


\section{MEDIA PEMBELAJARAN}

Media pembelajaran merupakan semua hal yang dapat membuat siswa mendapatkan pemahaman dalam proses pembelajaran, yaitu berupa pengetahuan, sikap, maupun keterampilan. Sehingga media dapat berupa maeri, contoh peristiwa, bahkan manusia sendiri misalnya figure tokoh, atau bahkan guru itu sendiri (Gerlach dan Ely, 1971).Media berfungsi menjembatasi hubungan antara siswa dan materi pembelajaran (Fleming, 1987), sehingga dalam pengertian lain, media dapat diartikan sebagai perantara informasi dari sumber (Heinich dkk, 1982). Sehingga, media pembelajaran merupakan media yang berisi materi yang memiliki tujuan atau mengandung maksud pengajaran / instruksional.

Dalam hal bentuk, Gagne dan Briggs (1979) menyebutkan bahwa media pembelajaran merupakan media yang berbentuk peralatan secara fisik yang dapat dipergunakan dalam mencapai tujuan pembelajaran.Adapun klasifikasi media pengajaran (Hamalik, 1985) terbagi menjadi 4, yaitu peralatan visual (dapat dilihat), auditif (dapat didengar), visual auditif (dapat dilihat dan didengar, dan dramatisasi (diperankan).

\section{MEDIA PEMBELAJARAN ANIMASI}

Menurut Tay Vaughan (2004), animasi perupakan perubahan bentuk gambar dalam waktu tertentu. Sedangkan menurut Utami (2011), serangkaian gambar yang digabungkan atau ditayangkan secara berurutan dan cepat sehingga membentuk gerakan. Kelebihan animasi adalah adanya faktor realism dari suatu fenomena, dimana animasi dapat membuat gambar sasaran menjadi lebih hidup dan tidak membosankan.Animasi dapat seperti menghidupkan gambar - gambar menjadi sebuah gerakan atau cerita.Sehingga animasi adalah pergerakan objek ataupun teks yang disusun dan dirancang secara khusus agar terlihat menarik dan lebih hidup.

Pada penjelasan konsep dan contoh contoh, digunakan animasi statis auto-run dan animasi interaktif. Adapun urutan kegiatan belajarnya adalah mendengarkan penyelesaian contoh, menyelesaikan soal-soal latihan, mendapatkan dan meminta penjelasan, dan selanjutnya menyelesaikan soal evaluasi (Suwarna, 2007).

Beberapa media pembelajaran yang berupa soft ware apliaksi yang populer diantaranya adalah microsot power point dan macromedia flash. PowerPoint sering digunakan untuk membuat presentasi bisnis, tetapi juga dapat digunakan untuk tujuan pendidikan atau informal.Presentasi terdiri dari slide, 
yang dapat berisi teks, gambar, dan media lain, seperti klip audio dan film.Efek suara dan transisi animasi juga dapat dimasukkan untuk menambah daya tarik tambahan untuk presentasi. Namun, efek suara dan transisi yang terlalu banyak mungkin akan berpotensi mengganggu audiens daripada menarik perhatian mereka. Sebagian besar presentasi PowerPoint dibuat dari template, yang termasuk warna latar belakang atau gambar, standar font, dan pilihan layout beberapa slide.Perubahan template dapat disimpan ke "slide master," yang menyimpan tema slide utama yang digunakan dalam presentasi.Ketika perubahan yang dibuat ke slide master, seperti memilih gambar latar belakang baru, perubahan tersebut disebarkan ke semua slide lainnya. Hal ini membuat tampilan seragam di antara semua slide dalam presentasi.

Sedangkan Macromedia Flash perangkat lunak yang dapat diunakan untuk membuat animasi menjadi seolah - olah hidup. Animasi yang dapat dibuat pada macromedia flash dapat dibedakan menjadi beberapa jenis, antara lain Animasi Frame by Frame, Motion Tween, dan shape tween. Animasi Frame by Frame dibuat menggunakan frame yang berbeda dalam satu layer dan antar layer. Animasi Motion Tween dapat disimulasikan untuk menggerakkan objek dari satu titik ke titik lainnya.Selanjutnya Animasi Shape Tween merupakan animasi yang digunakan untuk mengubah bentuk objek.

\section{STRATEGI PENGABDIAN}

Tahapan pengabdian masyarakat dibagi menjadi 3 tahapan, yaitu : pertama, Persiapan. Pada tahap persiapan dilakukan observasi terhadap media pembelajaran yang digunakan guru di sekolah. Observasi dilakukan untuk mengetahui media pembelajaran apa saja yang sering digunakan guru dalam mengajar. Setelah diketahui masalahnya maka disusun suatu solusi untuk diterapkan dalam tahap pelaksanaan.

Kedua, Pelaksanaan. Proses pelaksanaan terbagi menjadi 2, yaitu:

a) Sosialisasi, Tahap ini bertujuan untuk memberikan pengetahuan kepada guru-guru matematika bahwa terdapat teknologi yang dapat digunakan oleh guru untuk membuat media pembelajaran animasi. Teknologi tersebut berupa microsoft powerpoint dan flash.

b) Pelatihan, Pelatihan pengembangan media pembelajaran animasi berbasis komputer menggunakan microsoft powerpoint dan flash akan dilakukan secara praktik langsung. Masing-masing peserta akan memegang satu komputer dan langsung mempraktekkan apa yang dijelaskan oleh instruktur. Instruktur dan asisten ahli akan disediakan untuk membantu 
belajar para peserta. Pelatihan ini secara garis besar terdiri dari 3 topik utama, yaitu :

1) Pembuatan Media Animasi Menggunakan Microsoft Powerpoint

- Mempelajari Entrance Effects

- Mempelajari Emphasis Effects

- Mempelajari Exit Effects

- Mempelajari Motion Paths

- Mempelajari Effect Options

- Membuat media animasi

2) Pengenalan Dasar Mengenai Flash

Pada pelatihan yang kedua akan dikenalkan bermacam-macam menu dan elemen dasar Flash.

3) Pembuatan Media Animasi Menggunakan Flash

Setelah peserta mengenal menu dan elemen dasarpada flash maka peserta akan dilatih membuat media animasi.

Ketiga, Pendampingan. Kegiatan pendampingan akan dilaksanakan setiap minggu untuk memastikan bahwa guru-guru telah mengerti dan terampil dalam menggunakan microsoft powerpoint dan flash. Guru-guru mampu membuat media animasi baik yang menggunakan microsoft powerpoint maupun flash.

\section{KEGIATAN PENGUATAN KOMPETENSI GURU MATEMATIKA DALAM PENGEMBANGAN MEDIA PEMBELAJARAN ANIMASI BERBASIS KOMPUTER}

Kegiatan pelatihan pengembangan media pembelajaran animasi berbasis Power Point dan Macromedia Flash bagi guru matematika tingkat SMP/MTs dan SMA/MA/SMK/MAK se-kota Semarang di gedung Laboratorium Komputer Matematika Fakultas Sains dan Teknologi UIN Walisongo Semarang dilaksanakan Pada Sabtu, 21 Mei 2016. Pada kegiatan pertama diisi dengan pelatihan pembuatan media pembelajaran animasi menggunakan aplikasi Microsoft Power Point.Pada sepuluh menit pertama peserta didemonstrasikan sebuah aplikasi media pembelajaran interaktif yang dibuat menggunakan Microsoft Power Point.

Setelah selesai demonstrasi aplikasi tersebut, peserta diajak untuk membuat aplikasi semacam itu namun sebelumnya peserta terlebih dulu dikenalkan secara singkat tentang tampilan default microsoft power point mulai dari cara membuka program aplikasi Microsoft Power Point, pengenalan Work 
area beserta menu-menu dan toolbar-toolbar yang ada dan materi-materi yang terkait dengan langkah-langkah pembuatan media pembelajaran interaktif menggunakan aplikasi Microsoft Power Point. Sebagian besar peserta ternyata masih belum mengenal secara mendalam tentang fungsi-fungsi tool yang ada. Kebanyakan dari mereka memanfaatkan microsoft power point hanya sebagai media presentasi biasa, mengcopy-paste materi dari sumber lain kemudian ditampilkan dengan slide power point. Masih jarang yang menggunakan secara maksimal potensi yang ada dari microsoft power point untuk menciptakan media pembelajaran interaktif khususnya dalam pelajaran matematika.

Setelah secara singkat mengenal tool-tool yang ada dalam aplikasi tersebut, materi pertama yang disampaikan adalah membuat animasi pada suatu objek. Langkah langkah yang dilakukan adalah:

1. Klik pada menu Insert

2. Pada kolom Ilustrations pilih Shapes sehingga muncul pilihan objekobjek yang dapat dibuat. Dalam pelatihan tersebut kami meminta agar para peserta memilih objek oval.

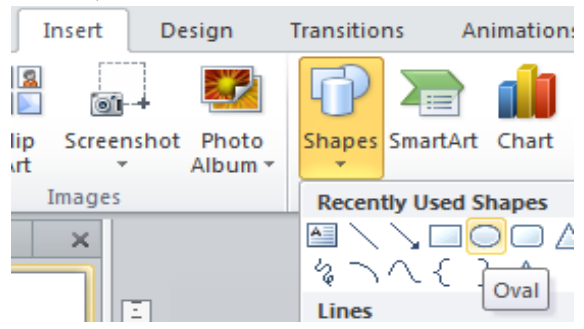

Gambar 3.1

Memilih Objek Oval pada menu Insert-Shapes

3. Kemudian buat objek oval di lembar slide dengan cara klik kiri tahan geser perlahan pada mouse.

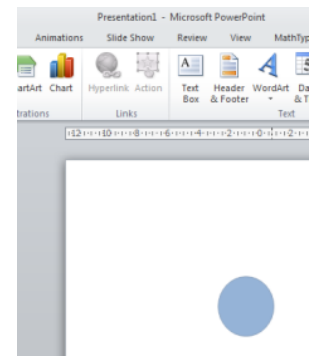

Gambar 3.2

Membuat Objek Oval 
4. Setelah objek oval selesai dibuat selanjutnya aktifkan objek tersebut dengan mengklik objek tersebut.

5. Selanjutnya klik menu Animations kemudian pada kolom Advanced Animation pilih Add Animation lalu pilih More Motion Paths sehingga muncul kotak dialog Add Motion Paths pilih Neutron lalu klik OK.

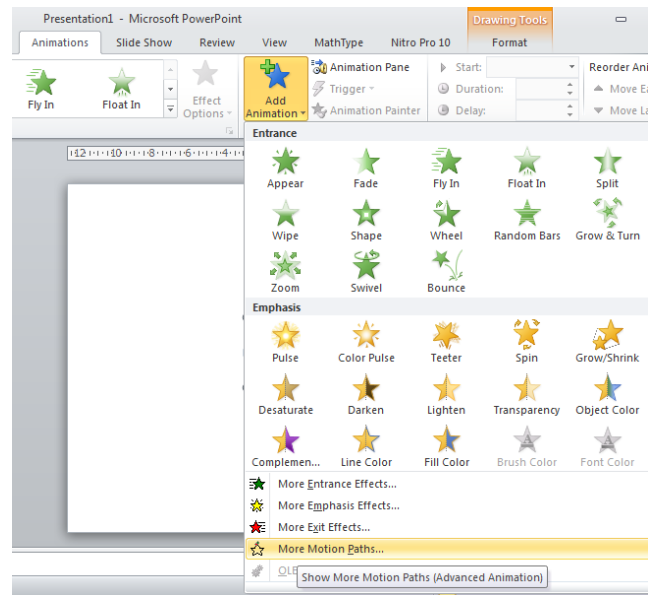

Gambar 3.3

Memunculkan kotak dialog add Montion Paths

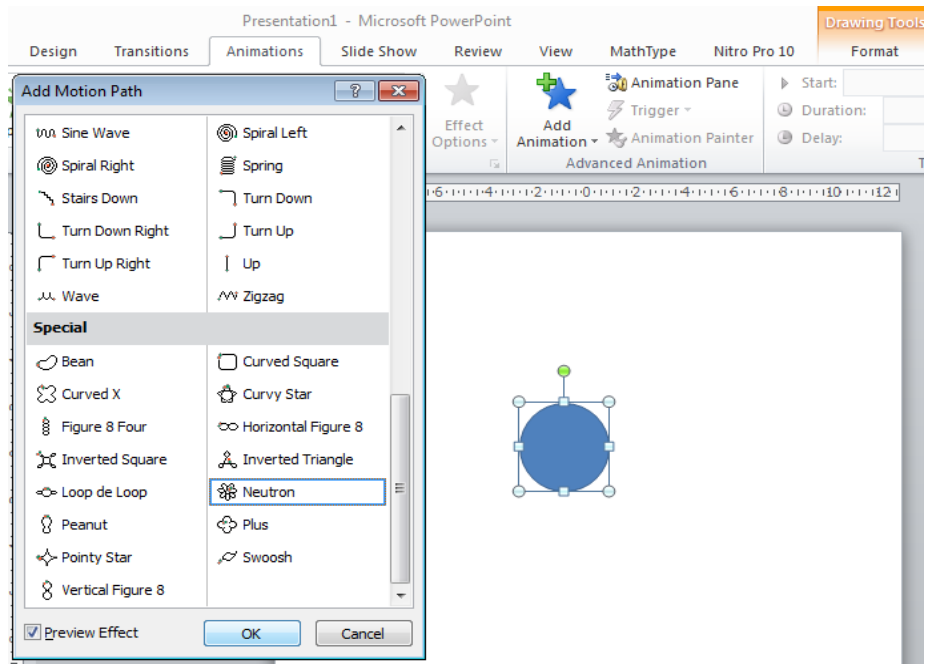

Gambar 3.4

Memberikan animasi Neutron pada objek 
Setelah membuat animasi objek, selanjutnya peserta diterangkan bagaimana mengatur animasi trsebut sesuai dengan keinginan kita diantaranya mengatur cepat-lambatnya animasi, pengulangan animasi, cara munculnya animasi apakah setelah klik, with previous atau after previous dengan cara sebagai berikut:

1. Pada menu Animations pilih Animation Pane pada kolom Advanced Animation, sehingga muncul kotak animation pane disebelah kanan slide.

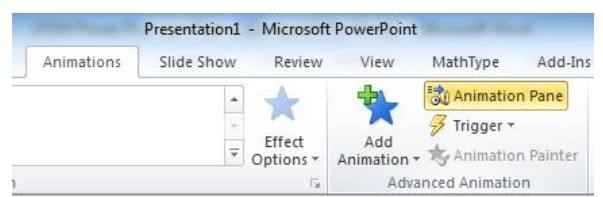

Gambar 3.5 Memunculkan Animation Pane

2. Klik segitiga hitam yang ada dibagian kanan animasi objek oval yang sudah dibuat tadi sehingga muncul pilihan seperti gambar di bawah lalu pilih Timming untuk memunculkan kotak dialog timming.
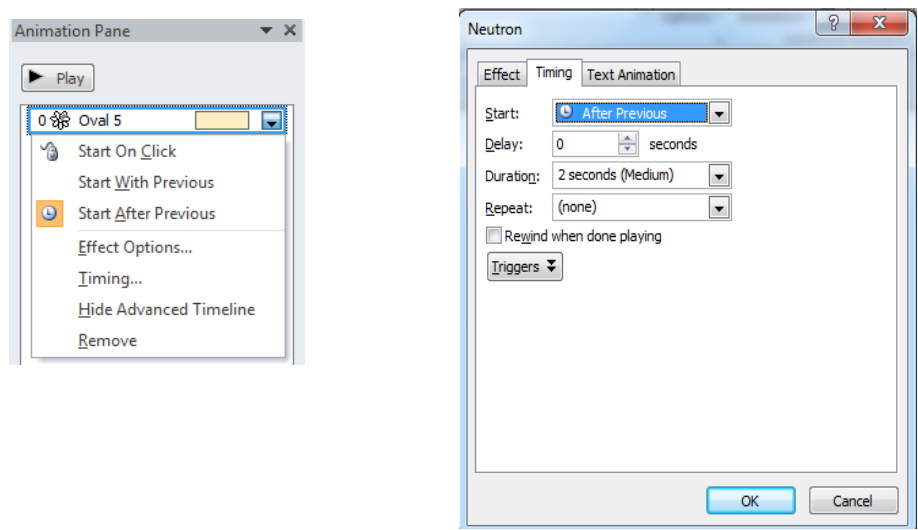

Gambar 3.6

Memunculkan kotak dialog pengaturan animasi

Dalam kotak dialog tersebut kita bisa mengatur efek animasi sesuai keinginan kita.

3. Setelah selesai mengatur animasi sesuai keinginan lalu klik OK.

Pada langkah-langkah membuat animasi pada objek tersebut ternyata tidak semua peserta bisa mengikuti dengan baik, sehingga langkah-langkah tersebut diulang sampai tiga kali. Beberapa alasan peserta kurang bisa mengikuti di antaranya sebagai berikut:

1. Pemateri terlalu cepat saat memberikan tutorial membuat animasi pada objek. 
2. Peserta masih banyak yang belum mengenal dengan baik mana yang disebut menu utama, kolom dan toolbar-toolbar yang ada dalam kolom pada setiap menu utama.

3. Langkah-langkah pembuatan animasi dan pengaturannya sesuai keinginan dirasa terlalu panjang.

Setelah lalngkah-langkah membuat animasi pada objek dapat dikuasai oleh peserta, mereka diminta membuat animasi pada objek yang mereka buat sesuai kreativitasnya masing-masing. Beberapa peserta hanya mengulang efek animasi yang sudah disampaikan pemateri. Terdapat pula peserta yang sudah diterangkan sampai tiga kali di depan belum bisa menguasai sehingga kami mendampingi satu-persatu peserta yang mengalami kesulitan.

Materi yang kedua yaitu membuat tombol action. Pertama, Peserta diminta untuk membuat slide baru dengan cara menekan toolbar New slide sebanyak dua kali sehingga sekarang memiliki tiga slide.Masing-masing slide diberi teks yang menunjukan urutan dari slide-slide tersebut. Slide 1 diberi teks "Halaman 1" dan seterusnya. Setelah selesai memberi teks pada tiap-tiap slide peserta diminta untuk memperhatikan langkah-langkah membuat tombol action yang disampaikan oleh narasumber. Langkah-langkah yang disampaikan narasumber adalaha sebagai berikut:

1. Klik menu insert, pada kolom Ilustrations pilih Shapes, klik Rounded Rectangle.

2. Buat objek Rounded Rectangle yang identik sebanyak tiga buah.

\section{Halaman 1}

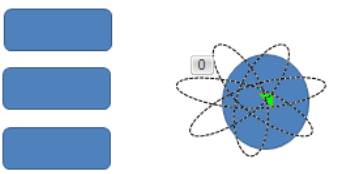

Gambar 3.7

Membuat objek tombol menggunakan Rounded Rectangle

3. Beri teks di dalamnya dari atas ke bawah "halaman 1", "halaman 2" dan "halaman 3" dengan cara klik kanan pada objek Rounded Rectangle lalu pilih Edit Text. Tujuan dari pemberian teks tersebut adalah ketika ditampilkan dan kita klik tombol halaman 2 maka slide akan berpindah menampilkan slide ke-2 (halaman 2) demikian halnya ketika diklik 
tombol halaman 3 maka slide akan berpindah menampilkan slide ke-3 (halaman 3).

4. Aktifkan tombol halaman 1 dengan cara klik tombol halaman 1. Pada menu Insert kolom Links pilih Action maka akan muncul kotak dialog Action Setting berikut. Pada Mouse Clik pilih Hyperlink to kemudian pilih slide sehingga akan muncul kotak dialog Hyperlink to Slide, karena tombol halaman 1 akan di link ke slide ke-1 maka pada kotak dialog Hyperlink to Slide pilih slide 1 lalu OK.

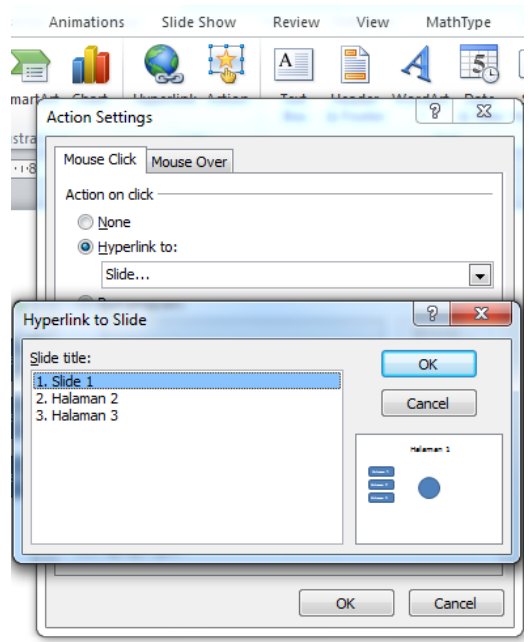

Gambar 3.8 Memberi action pada tombol

5. Lakukan hal yang sama pada tombol halaman 2 dan tombol halaman 3 .

6. Selanjutnya blok ketiga tombol tersebut lalu coppy dan paste di slide ke2 dan slide ke-3.

Setelah narasumber selesai memberikan tutorial tersebut, selanjutnya peserta diminta untuk melakukanya sendiri.Terdapat kekeliruan peserta yang kami temukan yaitu objek yang diberi Action bukan pada objek Rounded Rectangle melainkan pada teks yang terdapat dalam objek Rounded Rectangle.Hal ini menyebabkan teks yang ada di dalam objek Rounded Rectangle berubah warnanya menjadi biru disertai garis bawah pada teks.

\section{Halaman 1}

Gambar 3.9.

Kekeliruan saat memberi Action pada tombol 
Tim melakukan pendampingan kepada peserta yang masih mengalami kekeliruan saat membuat tombol action sampai semua peserta berhasil membuat tombol-tombol action yang sesuai dengan tutorial yang telah diajarkan.

Setelah selesai membuat tombol action, tutorial selanjutnya adalah membuat tombol Trigger. Langkah-langkah yang dipaparkan oleh narasumber adalah sebagai berikut:

1. Pada slide 1 buatlah tombol dengan bentuk oval do bawah tiga tombol yang sudah dibuat di awal. Berilah teks pada objek oval tersebut dengan kata Trigger seperti gambar berikut.

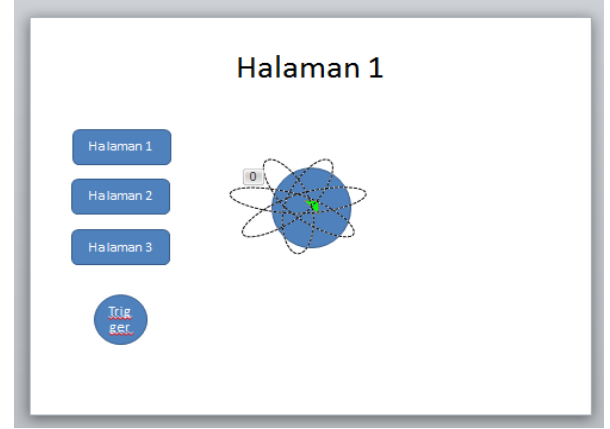

Gambar 3.10

Membuat tombol trigger

2. Blok ketiga tombol yang telah dibuat diawal, tambahkan animasi wipe.

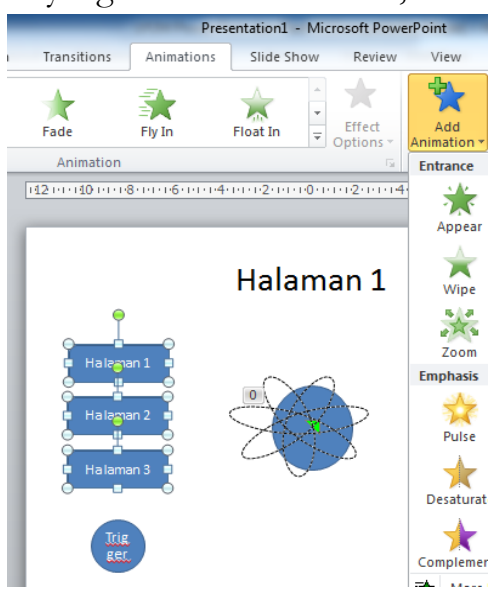

Gambar 3.11

Memberi animasi secara bersamaan 
3. Atur animasinya dengan memunculkan kotak dialog Timming sama seperti pada pembuatan animasi objek di awal. Buatlah tombol halaman 3 efek animasi berjalanan saat On Click dan tombol halaman 2 dan halaman 1 efek animasi berjalan saat After Previous. Seleksi semua animasi yang dikenakan pada tombol halaman 1,2, dan 3 kemudian klik icon Trigger lalu pilih nama objek yang dijadikan tombol trigger pada langkah nomor 1 .

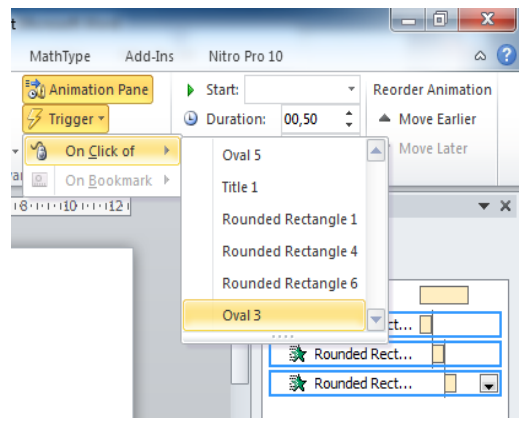

Gambar 3.12

Kotak dialog timming

4. Klik Add Animation pilih More Exit Effects sehinga muncul kotak dialog Exit Effects lalu pilih Wipe.

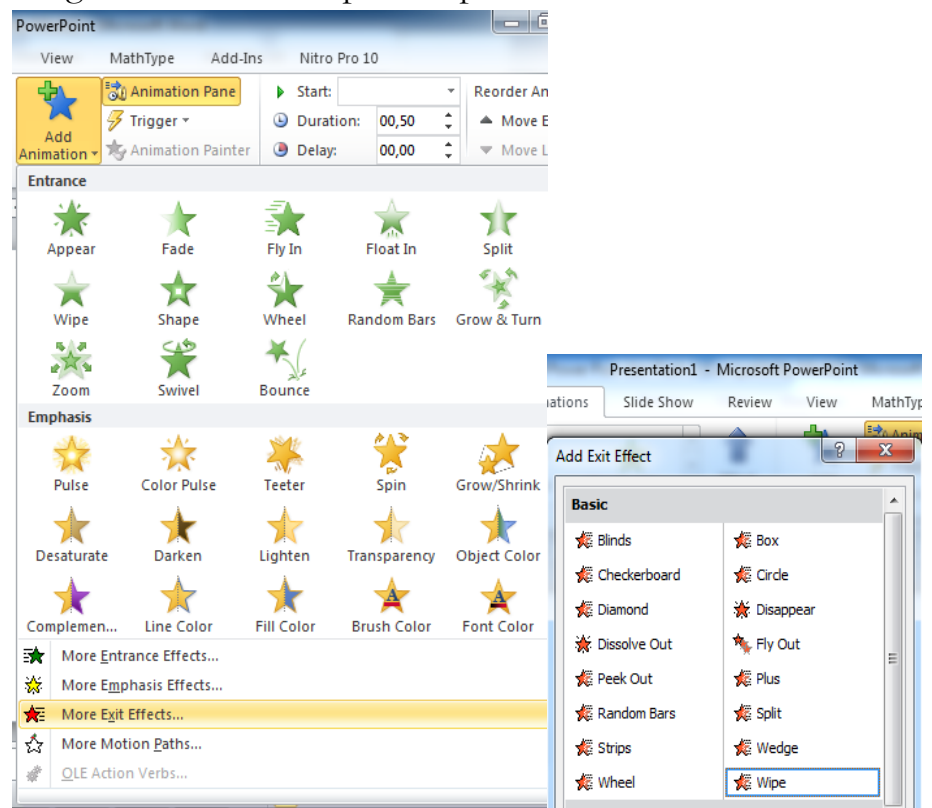

Gambar 3.13

Kotak dialog add animation 
5. Drag semua animasi exit effects ke bawah tombol trigger kemudian atur animasinya dengan memunculkan kotak dialog timming.

Tutorial pembuatan tombol trigger ini menurut peserta merupakan tutorial yang paling panjang dan susah diikuti karena langkah-langkah yang harus dilakukan relatif panjang. Banyak peserta yang meminta agar tutorial yang dilakukan oleh nara sumber diulang kembali. Setelah diulang sampai tiga kali kami melakukan pendampingan satu persatu agar semua peserta dapat membuat tombol triger sendiri.

Selama pelatihan pembuatan media animasi menggunakan microsoft powerpoint peserta merasa senang dan bersemangat karena banyak peserta yang merasa bahwa hal ini adalah sesuatu yang baru dikenal dalam power point dikarenakan selama ini penggunaan microsoft Power poin terbatas hanya menampilkan teks saja. Setelah selesai materi pertama dilanjutkan dengan materi kedua, yaitu pembuatan media pembelajaran animasi menggunakan Macromedia Flash.

Pelatihan Macromedia Flash ini diawali dengan mengenalkan work area pada tampilan awal Macromedia Flash. Peserta juga diterangkan secara singkat tentang menu-menu yang ada dan tool-tool yang dapat digunakan dalam membuat karya menggunakan macromedia flash. Karena semua peserta mendapatkan modul pemrograman komputer Macromedia flash sehingga tidak terlalu lama pada tahap ini dijelaskan. Peserta diminta untuk mendalaminya lebih lanjut secara mandiri.Pertama, peserta dikenalkan tentang tool gambar dan tool warna.Kedua, peserta diajarai mengatur tampilan stage.Ketiga, peserta dikenalkan dengan contoh menggambar objek.Objek yang dibuat dalam pelatihan adalah membuat objek oval.Dalam menggamabar objek seperti lingkaran dan kotak, secara otomatis macromedia flash menyediakan 2 unsur objek, yaitu fill (bidang) dan stroke (garis).

Peserta juga diberitahu bagaimana mengatur fill dan stroke saat menggambar objek dengan cara memilih warna sesuai yang diinginkan dibagian colors. Dengan mengklik segitiga hitam di pojok kanan bawah maka akan muncul palet-palet warna yang beraneka ragam sehingga kita bisa meilih warna apa yang kita inginkan.

Setelah diterangkan materi tersebut, peserta diminta membuat tiga jenis objek yaitu, objek dengan fill dan stroke dengan warna yang berbeda, objek tanpa fill, dan objek tanpa stroke.

Setelah semua peserta bisa mengikuti dan mampu menggambar ketiga objek tersebut dengan benar, materi dilanjutkan yaitu, mengubah warna objek yang sudah dibuat. 


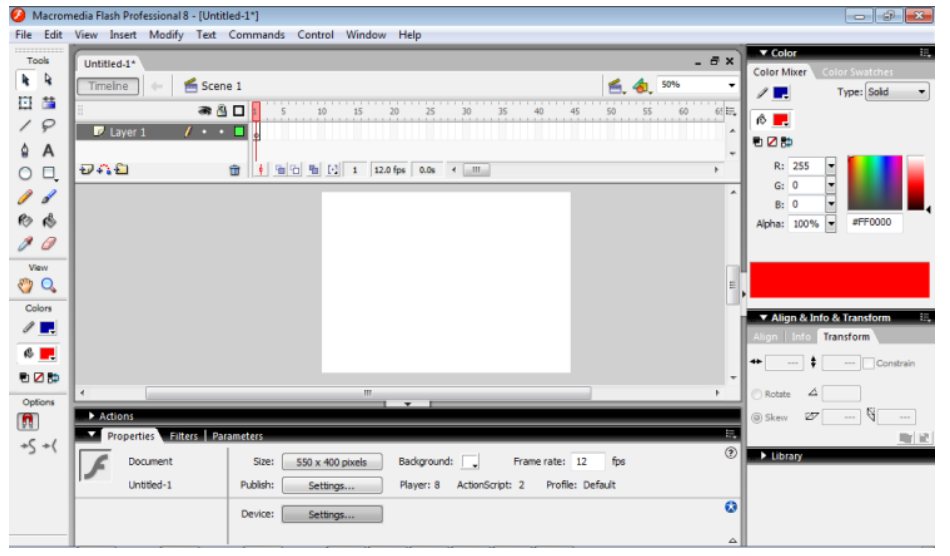

Gambar 3.14

Tampilan work area Macromedia Flash

Langkah-langkah yang diberikan adalah, pilih selection tool, klik pada fill objek, lalu pilih warna yang diinginkan di bagian color sehingga warna objek yang tadi dibuat berubah warnanya sesuai yang kita inginkan.

Setelah semua peserta bisa mengubah warna objek baik warna fill maupun warna stroke, selanjutnya peserta diterangkan cara membuat gradasi warna pada objek yang sudah dibuat.

Peserta diminta untuk memperhatikan kembali tutorial dari narasumber.Pada kotak color di bagian pojok kanan atas, type diganti dengan linier kemudian ubah pewarnaanya dengan kombinasi dua warna atau lebih.

Setelah dilakukan pendampingan dan peserta mengeksplor kemampuannya untuk membuat berbagai objek dan berbagai gradasi, tutorial dilanjutkan menggambar dengan tool pencil. Ada tiga jenis pencil yang tersedia yaitu: Straighten yang digunakan untuk membuat garis lurus, smoth untuk membuat garis sedikit melelngkung, dan ink untuk membuat garis sesuai yang kita gambar.

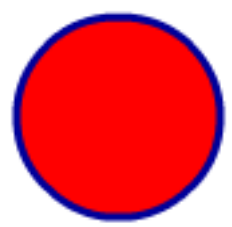

Gambar 3.15

Objek oval dengan fill merah dan stroke biru 
Emy S.

Penguatan Kompetensi Guru Matematika...

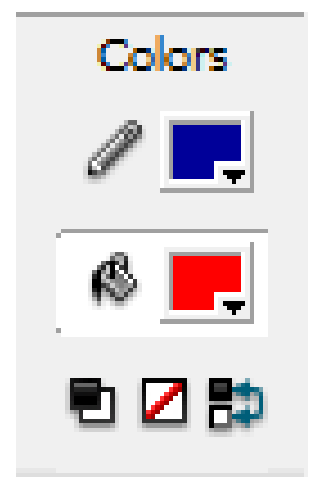

Gambar 3.16

Tool colors
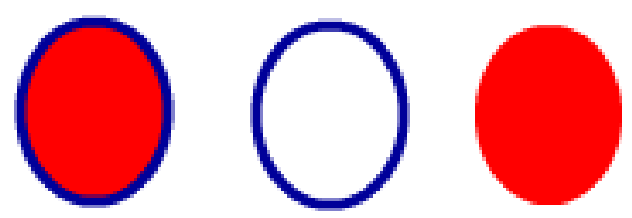

Gambar 3.17

Objek dengan jenis yang berbeda
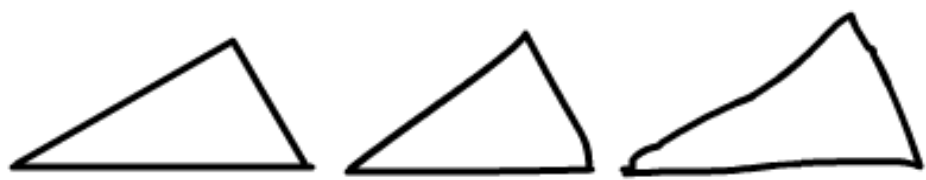

Gambar 3.18

Segitiga yang dibuat dari pencil straigten, smoth dan ink

Peserta diminta untuk membuat bangun datar selain segitiga dengan masing-masing bangun datar yang digambar mengggunakan pencil straighten, smoth dan ink.

Tutorial berikutnya adalah materi tentang intersection atau pemotongan.Peserta diberikan contoh sebuah objek lingkaran yang dipotong dengan sebuah persegi panjang. 

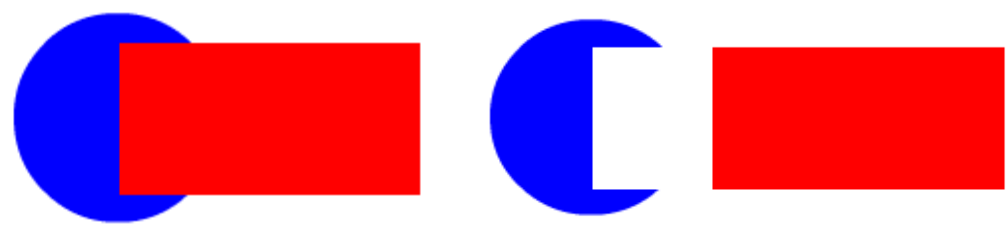

Gambar 3.19

Proses intersection

Setelah membuat intersection pada fill objek, peserta diminta untuk mencoba membuat intersection pada objek yang hanya menggunakan stroke saja. Kami mendampingi satu persatu peserta yang masih merasa kesulitan untuk emmbuat intersection pada objek.

Materi macromedia flash selanjutnya adalah pelatihan animasi frame by frame. Animasi frame by frame dibuat tanpa menggunakan property tween, tetapi dengan mengganti bentuk objek pada tiap frame-frame berikutnya.Para peserta pelatihan di tunjukan suatu animasi frame by frame sesuai dengan yang ada pada modul, animasi yang menunjukan pergerakan objek yang menyerupai manusia tersebut menjadi pusat perhatian para peserta.Bersamaan dengan kegiatan pengamatan ini, peserta pelatihan mendapat penjelasan tentang animasi frame by frame dari narasumber.Kemudian narasumber membuka kesempatan bagi peserta untuk mengajukan pertanyaan maupun pendapatnya, namun pada kesempatan ini belum ada pertanyaan yang diajukan.

Peserta pelatihan diperlihatkan kembali tentang hasil animasi yang menggunakan frame by frame terkait dengan bangun dimensi tiga. Bangun tersebut adalah kubus dengan sisi-sisi yang memiliki warna berbeda sehingga terkesan menarik.Pada animasi tersebut, terlihat suatu kubus yang untuh mulai bergerak dengan membukanya satu persatu sisi kubus hingga berubah menjadi jaringjaring kubus. Kubus tersebut bergerak dari membukanya sisi atas kubus dilanjutkan sisi kanan kemudian sisi depan dan sisi kanan diakhiri dengan sisi belakang yang bergerak sejajar dengan sisi bawah sehingga terlihatlah sebuah jaring-jaring kubus. Pada kegiatan ini para peserta pelatihan macromedia flash terlihat sangat antusias untuk bisa membuat animasi serupa.

Narasumber menyampaikan apersepsi tentang materi sebelumnya terkait fungsi-fungsi tools terutama pada Line tool, rectangle tooldan juga pewarnaan pada objek (colors). Sebelum membuat suatu objek, peserta pelatihan diarahkan untuk menampilkan grid pada stage untuk memudahkan dalam pembuatan kubus dengan ukuran yang tepat. Langkah-langkah untuk menampilkan grid adalah:

1. Pilih menu View 
2. Pilih Grid $\rightarrow$ Show Grid

\begin{tabular}{|ll|llr|}
\hline Grid & $>$ & Show Grid & Ctrl+' \\
\hline Guides & $>$ & Edit Grid... & Ctrl+Alt+G \\
\hline Snapbina & $>$ & & \\
\hline
\end{tabular}

Gambar 3.20

Kotak dialog grid

Atau bisa juga dengan menggunakan short key dengan menekan tombol ctrl dan tanda petik satu secara bersamaan (Ctrl+').Peserta pelatihan mulai membuat suatu persegi dengan stroke color dan fill color sesuai dengan warna yang dikehendaki masing-masing. Setelah selesai membuat persegi untuk sisi depan kubus, para peserta melanjutkan membuat rusuk-rusuk dengan line tool kemudian dilanjutkan lagi dengan pewarnaan. Pada tahap ini terdapat beberapa paserta yang mengalami kendala dalam memberi warna fill pada sisi-sisi yang lain. Masalah tersebut muncul karena garis yang dilukis untuk membuat rusuk pada kubus tersebut tidak benar-benar tertutup.Masih ada celah pada gambar sehingga pewarnaanpun tidak bisa dilakukan.

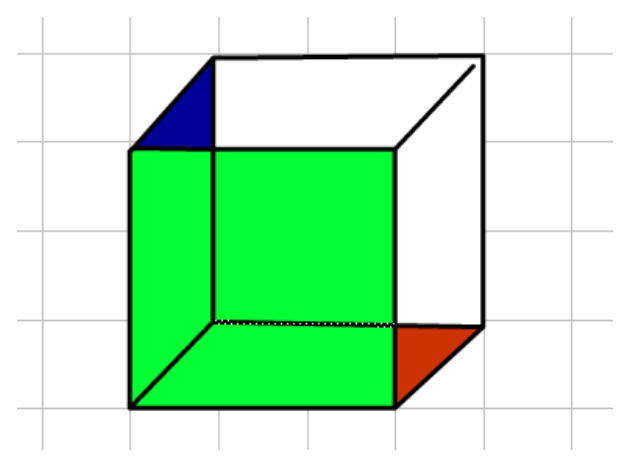

Gambar 3.21

Gambar kubus yang telah diberi warna

Untuk mengatasi masalah tersebut, langkah pertama adalah dengan memperbesar (zoom in) stage agar lebih terlihat jelas kemudian melakukan pengulangan pembuatan garis untuk rusuk dan dipastikan benar-benar tertutup agar pewarnaan bisa dilakukan. Kendala yang muncul selanjutnya adalah lokasi kubus pada stage yang terlalu dekat dengan tepi sehingga kubus tersebut akan kekurangan ruang saat berubah menjadi suatu jaring-jaring kubus. Solusi dari 
masalah tersebut adalah dengan men-select all kubus tersebut dan di drag menuju tengah stage dan dipastikan Selection toolaktif.

Pada tahap pertama tentang pembuatan kubus ini pun terasa cukup tanpa ada kendala lagi kemudian dilanjutkan dengan membukanya sisi atas kubus. Peserta pelatihan mulai membuat sisi atas kubus yang terbuka dengan menggunakan line tool dan dengan ukuran yang sesuai dengan perhitungan pada grid dan pada jarak frame yang berbeda dengan menggunakan fungsi insert keyframe yang didapat diri kegiatan klik kanan pada timeline.

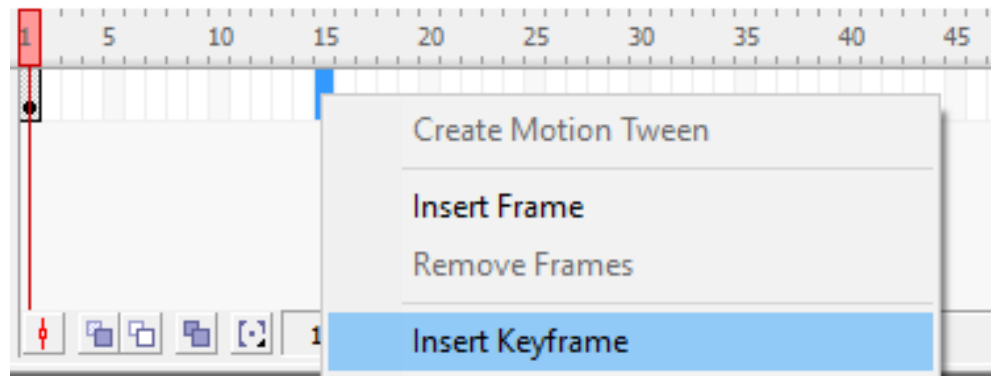

Gambar 3.22

Tampilan insert keyframe

Kembali lagi dengan teknik pewarnaan dengan warna yang berbeda untuk masing-masing sisi. Dilanjutkan dengan pembuatan sisi-sisi yang lainnya dan dengan jarak frame yang berbeda-beda pula. Pada kegiatan ini masalah yang timbul masih sama, yaitu terkait pewarnaan dan ditambah lagi dengan ukuran sisi-sisi pada jaring-jaring kubus yang terlihat kurang profesional. Solusi yang dilakukanpun masih sama dengan memperbesar stage terlebih dahulu dan memperhitungkan jarak yang telah dibantu dengan adanya Grid.

Setelah semua peserta pelatihan selesai membuat jaring-jaring, langkah berikutnya adalah menampilkan serangkaian gambar tersebut menjadi sebuah animasi dengan cara:

1. Pilih menu control

2. klik pada Test Movie

Atau bisa juga dengan menggunakan short key dengan menekan ctrl dan enter secara bersamaan. Jika langkah-langkah diatas di lakukan maka akan keluar jendela baru yang menampilkan jalannya animasi jaring-jaring kubus. Cara lain untuk menampilkan animasi adalah dengan menggunakan fungsi play pada menu control juga, dengan menggunakan cara ini animasi akan berjalan langsung pada stage. Kendala-kendala yang terjadi pada langkah ini adalah peserta terkejut 
dengan animasi pada bagian akhir yang berjalan begitu cepat.Hal tersebut terjadi karena pada timeline terakhir tidak diberi jarak.

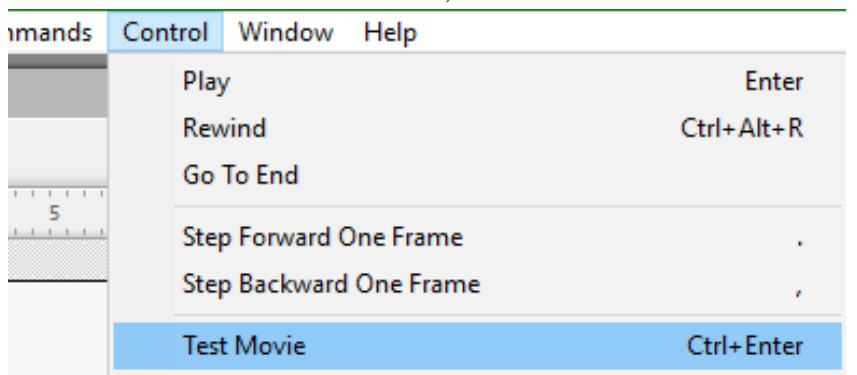

Gambar 3.23

Kotak dialog untuk menampilkan animasi

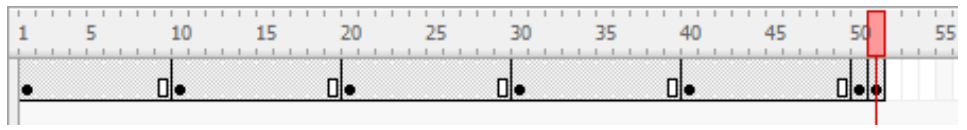

Gambar 3.24 jarak antar frame

Dapat diamati bahwa jarak antara frame adalah 10, namun pada frame terakhir tidak diberi jarak sama sekali dari frame 50 ke frame 51. Jadi sudah jelas untuk mengatasi permasalahan tersebut adalah dengan memberi jarak pada frame terakhir dengan insert keyframe.

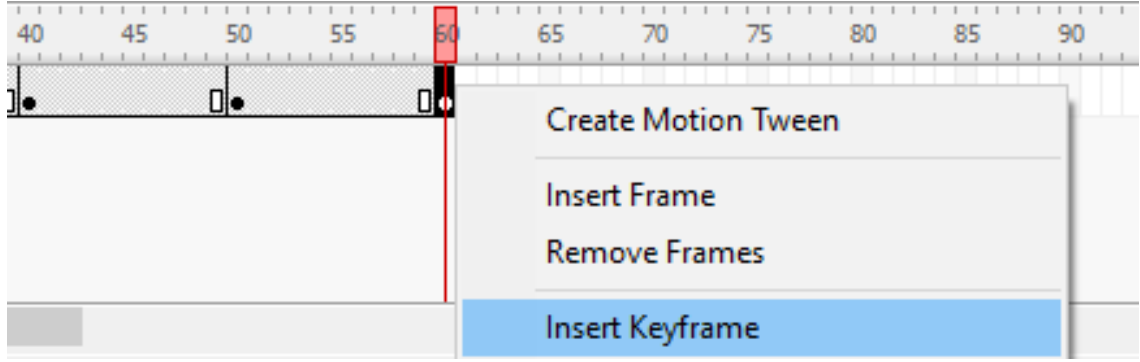

Gambar 3.25

insert keyframe untuk mengatur jarak antar frame

Dengan berhasil berjalannya animasi frame by frame bentuk kubus yang berubah menjadi jaring-jaring kubus, maka materi telah selesai dan dilanjutkan dengan materi untuk membuat kalkulator.

Adapun kalkulator yang ditampilkan memuat penjumlahan, pengurangan, perkalian, pembagian, dan akar.Angka yang dimasukan secara acak dengan menekan tombol random, jadi animasi yang ditunjukan tidak bisa 
dimasukan suatu bilangan yang sesuai keinginan.Narasumber memberi penjelasan mengenai pembuatan kalkulator tersebut dengan menunjukan scriptscript pada actions untuk pengoperasikan angka-angka yang muncul.

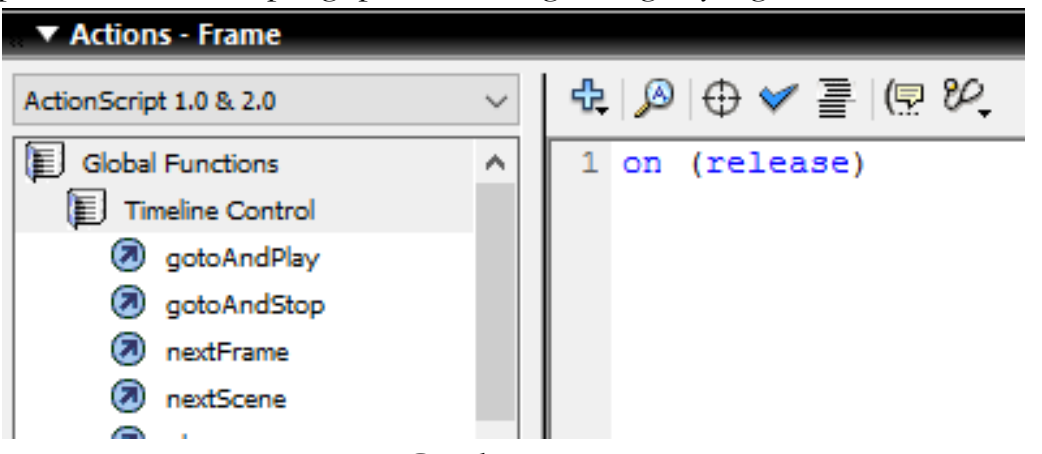

Gambar 3.26

Tampilan action pada macromedia flash

Berhubung waktu hampir berakhir, maka pada materi kalkulator ini para peserta pelatihan hanya didemonstrasikan saja tidak mempraktikannya.Dengan selesainya materi kalkulator tersebut, maka berakhir pula pelatihan power point dan macromedia flash ini. Narasumber mengucapkan terimakasih dan salam penutup kepada peserta pelatihan.

Setelah penutupan, tim pelatihan meminta kepada peserta untuk mempraktikan materi yang telah diperoleh hari ini untuk membuat media animasi baik menggunakan powerpoint maupun macromedia flash. Media yang nantinya telah berhasil peserta buat dapat digunakan dalam pembelajaran matematika.

Pada hari selanjutnya, dilaksanakan pendampingan ke beberapa peserta pelatihan untuk memberikan informasi yang lebih detail mengenai power point dan macromedia flash yang belum sempat disampaiakan pada saat pelatihan. Pendampingan juga untuk menjawab beberapa pertanyaan atau keingintahuan peserta pelatihan tentang penggunaan dan fungsi keseluruhan software powerpoint dan macromedia flash. Selain itu, pendampingan juga dilakukan untuk mengetahui sejauh mana peserta telah berhasil dalam membuat media pembelajaran animasi, baik menggunakan microsoft powerpoint maupun macromedia flash. Pendampingan ke peserta pelatihan dilakukan di 4 sekolah, yaitu SMA N 13 Semarang, SMP N 16 Semarang, SMK NU Ma'arif, dan MTs Darul Ulum.

Pendampingan di SMA N 13 Semarang dilaksanakan hari selasa tanggal 24 Mei 2016 jam 13.00 WIB di ruang perpustakaan. Dalam pendampingan ini, 
guru matematika SMA 13 Semarang Bapak Agus Sudarsono, S.Pd di demonstrasikan media pembeljaran menggunakan software powerpoint. Materi yang akan ditunjukan adalah dimensi tiga. Pada presentasi materi kelas $\mathrm{X}$ ini akan diperlihatkan animasi tentang kedudukan titik, garis dan bidang dalam ruang dimensi tiga. Selanjutnya, tidak ada pertanyaan yang diajukan oleh Bapak Agus Sudarsono, S.Pd karena penjelasan yang diberikan sudah cukup jelas.

Kemudian dilanjutkan demonstrasi selanjutnya tentang media pembelajaran menggunakan software macromedia flash.Materi yang dipresentasikan adalah persamaan kuadrat.Dalam presentasi ini diawali dengan animasi untuk tombol masuk kemudian dilanjutkan dengan tampilan beranda yang didapati berbagai tombol seperti tombol menu untuk menujukan daftar materi dan progam untuk masing-masing indikator, tombol home untuk kembali ke beranda, tombol profil dan tombol exit untuk menutup presentasi. Dalam presentasi ini Pak Agus Sudarsono terlihat antusias dan mulai meluncurkan berbagai pertanyaan tentang media ini.Pak Agus Sudarsono sangat antusias terkait progam yang dapat menghitung suatu persoalan dalam matematika sepertihalnya sebuah kalkulator.Sehingga pertanyaan untuk membuatnya pun disampaikan oleh beliau.

Setelah tim pendampingan mendemonstrasikan media pembelajaran animasi, Pak Agus Sudarsono menampilkan media pembelajaran yang telah berhasil beliau buat. Media pembelajaran yang beliau buat menggunakan microsoft powerpoint. Media tersebut merupakan media untuk materi grafik fungsi trigonometri. Media yang Pak Agus buat sudah bagus dan hanya mendapat masukan sedikit dari tim pendampingan. Untuk media animasi yang menggunakan macromedia flash, pak Agus baru berhasil membuat menu utama.

Pendampingan di SMP N 16 Semarang dilakukan tanggal 23 Mei 2016. Tim pendampingan bertemu dengan Ibu Sri Rejeki, M.Pd. Ternyata ibu Sri Rejeki, M.Pd mempunyai banyak koleksi media pembelajaran animasi berbasis powerpoint maupun macromedia flash. Media tersebut ada yang dibuat sendiri, ada pula yang didownload dari internet. Karena ibu Sri Rejeki, M.Pd telah mampu membuat sendiri media animasi maka tim pendampingan tidak mendemonstrasikan media animasi yang telah disiapkan.

Tanggal 25 Mei 2016, tim pendampingan melakukan pendampingan di SMK NU Ma'arif. Guru matematika yang menjadi peserta pendampingan adalah Ibu Zustina Indriyati, S.Pd. Beliau telah berhasil membuat media animasi berbasis microsoft powerpoint untuk materi irisan kerucut. Namun, beliau belum berhasil membuat media animasi berbasis macromedia flash. Ibu Zustina 
Indriyati masih kesulitan untuk membuat sendiri media animasi menggunakan macromedia flash.

Pendampingan di MTs Darul Ulum dilaksanakan tanggal 26 Mei 2016. Tim pendampingan menemui ibu Ika Retnawati, S.Pd. Ibu Ika Retnawati mendemonstrasikan media animasi yang telah ia buat untuk materi kesebangunan yang menggunakan powerpoint dan bangun datar yang menggunakan macromedia flash.

Setelah dilakukan pelatihan dan pendampingan kepada para guru, diketahui bahwa para guru merasakan manfaat yang nyata dari pelatihan dan pendampingan yang telah dilakukan. Guru merasa pengetahuannya bertambah dan dapat membuat sendiri media pembelajaran animasi berbasis komputer.

Hasil kegiatan yang diperoleh dari pelatihan dan pendampingan pengembangan media pembelajaran animasi berbasis komputer adalah :

1. Selama pelatihan, peserta telah berhasil membuat media animasi menggunakan microsoft powerpoint yang dicontohkan narasumber

2. Selama pelatihan, peserta telah berhasil mengoperasikan dan membuat media animasi menggunakan macromedia flash yang dicontohkan narasumber

3. Peserta pendampingan, telah berhasil membuat sendiri media animasi menggunakan microsoft powerpoint

4. Sebagian peserta pendampingan, telah berhasil membuat sendiri media animasi menggunakan macromedia flash

\section{KESIMPULAN DAN REKOMENDASI}

Kegiatan pengabdian masyarakat ini bertujuan agar guru matematika dapat membuat sendiri media pembelajaran animasi berbasis komputer. Dengan membuat sendiri media animasi tersebut guru dapat menambah pengatahuannya serta dapat meningkatkan kreativitasnya.

Dari kegiatan pelatihan dan pendampingan yang telah dilakukan dapat diambil kesimpulan bahwa guru matematika sangat tertarik pada materi yang narasumber sampaikan. Sebagian besar guru baru mengetahui bahwa microsoft powerpoint tidak hanya untuk presentasi saja tetapi juga dapat digunakan untuk membuat media animasi. Guru juga tertarik dengan materi baru mengenai macromedia flash.Meskipun masih awam mengenai software flash, namun peserta antusias untuk mengikuti pelatihan.

Peneliti telah melakukan pendampingan di 4 sekolah. Dari hasil pendampingan diperoleh bahwa bapak Agus Sudarsono, S.Pd dari SMA N 13 Semarang telah berhasil membuat media animasi menggunakan powerpoint. 
Untuk media macromedia flash pak Agus baru membuat tampilan menu awal untuk materi matriks. Ibu Sri Rejeki, M.Pd dari SMP N 16 Semarang dan Ibu Ika Retnawati, S.Pd dari MTs darul Ulum telah berhasil membuat media animasi baik menggunakan powerpoint maupun flash. Sementara ibu Zustina Indriyati, S.Pd baru berhasil membuat media animasi menggunakan powerpoint saja.

Melihat manfaat yang nyata dari pelatihan dan pendampingan pengembangan media pembelajaran animasi berbasis komputer, maka perlu dibuat modul panduan yang lengkap tentang cara-cara pembuatan media animasi menggunakan Microsoft PowerPoint dan Macromedia Flash.

\section{DAFTAR PUSTAKA}

Fleming, M. 1987. Displays and communication.In R. M. Gagne (Ed.), Instructional technology foundations (pp. 233-260).Hillsdale, NJ: Erlbaum.

Gagne, Robert M. dan Leslie, J. Briggs. 1979. Principles of Instructional Design, second edition, New York : Holt, Rinegan, and Winston.

Gerlach, V.G. dan Ely, D.P. 1971.Teaching and Media. A. Systematic Approach. Englewood Cliffs: Prentice-Hill, Inc.

Hamalik, Oemar. 1985. Media Pendidikan. Bandung: Alumni.

Heinich, R., Molenda, M., dan Russell, J.D. 1982.Instructional Media and The New Technologies of Instruction. New York : John Wiley \& Sons.

Latuheru, John D. 1988. Media Pembelajaran dalam Proses Belajar Mengajar Masa Kini.Jakarta : Departemen Pendidikan dan Kebudayaan.

Suwarna, I. P. 2007. Model Pembelajaran Fisika Interaktif melalui Program Macromedia Flash (Computer Based Instruction). http://iwanpermana.blogspot.co.id/ .Diakses pada tanggal 1 September 2016.

Utami, Dina. 2011. Animasi dalam Pembelajaran. Majalab Ilmiah Pembelajaran, No. 1 Vol. 7, Mei 2011. http://journal.uny.ac.id/index.php/mip/article/viewFile/3212/2692 .Diakses pada tanggal 1 Februari 2016. 
Vaughan, Tay. 2004. Multimedia: Making It Work. Sixth Edition.McGraw-Hill Technology Education. 